Jurnal Agroteknologi, Vol. 6 No. 1, Agustus $2015: 17$ - 24

\title{
UPAYA PENINGKATAN HASIL MENTIMUN SECARA ORGANIK DENGAN SISTEM TASALAMPOT
}

\author{
(Increasing the Yields of Cucumber by Tasalampot Organic Farming System)
}

INDAH PERMANASARI DAN AULIA RANI ANNISAVA

Program Studi Agroteknologi, Fakultas Pertanian dan Peternakan

Universitas Islam Negeri Sultan Syarif Kasim Riau

JI. H.R. Soebrantas No. 155 KM 18 Simpang Baru Panam Pekanbaru Riau 28293

e-mail: amalia_permanasari@yahoo.co.id

\begin{abstract}
Utilization of organic material in crop farming is one of the methods to exploit the local wisdom in agricultural practice. The research was conducted from June to September 2012 in the research farm, State Islamic University of Sultan Syarif Kasim Riau. The objective of the research was to investigate the effects of organic materials and crop density? in growth and yield on cucumber. Randomized block design with 2 factors and 4 replications was employed in this study. The first factor consists of three levels organic fertilizer treatments i.e. no fertilizer, poultry manure, and compost of oil palm empty bunch. Second factor comprises of three levels of crop density i.e. 1, 2, and 3 plants per pot).. The results showed that there was significant increase on growth and yield on cucumber with poultry manure treatment compare to that of with compost of oil palm empty bunch. Increasing crop density ? improves the number and weight of cucumber yield per pot, even though, some parameters, i.e. number of leaves, stem diameter, crop dry weight, productive number of branches, cucumber size and cucumber weight per plant were significantly decreased.
\end{abstract}

Keywords : cucumber, chicken manure, compost of oil palm empty bunch, plant population

\section{PENDAHULUAN}

Mentimun merupakan salah satu jenis sayuran populer yang banyak mengandung vitamin dan mineral. Di Asia, tanaman ini menduduki peringkat keempat setelah tomat, kubis dan bawang (Tatliogu, 1997 cit. Eifediyi \& Remison, 2010). Sayuran yang termasuk ke dalam famili cucurbitaceae ini bermanfaat bagi kesehatan karena dapat membantu pencernaan, menetralkan zat asam dan mencegah penyakit sariawan. Menurut Sumpena (2001), mentimun merupakan sayuran yang mempunyai nilai gizi. Setiap 100 $\mathrm{g}$ mentimun mengandung 15 kalori, $0,8 \mathrm{~g}$ protein, $0,10 \mathrm{~g}$ pati, $3 \mathrm{~g}$ karbohidrat, $30 \mathrm{mg}$ fosfor, $0,5 \mathrm{mg}$ zat besi, $14 \mathrm{mg}$ asam, 0,45 vitamin $A, 0,30$ vitamin $B 1$ dan 0,20 vitamin $B 2$. Budidaya mentimun secara konvensional menggunakan pupuk dan pestisida kimia. Penggunaan input kimia yang tidak bijaksana bisa menimbulkan dampak yang tidak baik, yaitu pemicu penurunan titik balik produksi, sehingga menyebabkan semakin terpuruknya kehidupan petani. Penggunaan input kimia ini selama bertahun-tahun akan mengganggu keseimbangan ekosistem, tanah menjadi keras, terjadinya pencemaran lingkungan dan hasil panen menjadi kurang enak serta mudah rusak (Sutanto, 2002). Pertanian organik menggunakan pupuk kandang ayam, kompos tandan kosong (tankos) sawit dan ekstrak tanaman terfermentasi (ETT) adalah alternatif pengganti pupuk dan pestisida kimia. Hasil penelitian Eifediyi dan Remison (2010), kombinasi antara pupuk kandang 10 ton/ha dan pupuk NPK (20:10:10) $400 \mathrm{~kg} / \mathrm{ha}$ secara nyata meningkatkan panjang batang, jumlah daun, berat buah/tanaman dan hasil buah mentimun per hektar. Peningkatan berat buah per hektar mencapai $166,42 \%$ dibandingkan perlakuan kontrol. Hasil penelitian Martinez et al. (2012) pemberian pupuk kandang ayam meningkatkan pembukaan kotiledon; berat basah, kering dan panjang bunga; mempercepat pembungaan, dan meningkatkan berat kering tanaman pepo dibandingkan tanpa pemupukan maupun penggunaan pupuk organic yang lain.

Pupuk kompos tandan kelapa sawit merupakan limbah padat dari pabrik kelapa sawit (PKS). Ketersediaan tandan kosong sawit sangat banyak seiring dengan bertambahnya luas areal perkebunan kelapa sawit. Hasil 
penelitian Mutiara (2008), menunjukkan bahwa pemberian kompos tandan kosong kelapa sawit rata - rata yang terbaik adalah pemberian 30 ton kompos/ha pada pertumbuhan dan produksi tanaman kailan. Hasil penelitian yang dilakukan oleh Mahmoud et al. (2009) pemberian kompos tanaman yang berasal dari jerami, batang pohon jagung, kulit kacang, sisa-sisa daun kubis dan daun bit menghasilkan berat buah dan berat kering tajuk mentimun terbaik dibandingkan dengan pemberian kompos hewan maupun campuran kompos hewan dan tanaman. Penggunaan kompos tanaman ini juga dapat digunakan untuk menggantikan \pm 25 $\%$ kebutuhan nitrogen yang berasal dari pupuk kimia tanaman mentimun.

Populasi tanaman per pot juga akan mempengaruhi pertumbuhan dan hasil mentimun. Semakin banyak populasi, maka akan semakin tinggi tingkat persaingan dalam memperoleh air, unsur hara dan cahaya matahari, sehingga akan berpengaruh terhadap pertumbuhan dan hasil mentimun. Hasil penelitian Kusrini (2006) peningkatan kerapatan tanam dari 5 tanaman $/ \mathrm{m}$ menjadi 7 tanaman $/ \mathrm{m}$ dapat menurunkan jumlah daun selada pada umur 19 dan 24 hst.

Penelitian tentang pemanfaatan pupuk kandang ayam dan kompos tandan kosong kelapa sawit dengan populasi berbeda diharapkan dapat meningkatkan pertumbuhan dan hasil mentimun yang berkualitas, sehat, bebas pestisida,dan memiliki kandungan antioksidan yang tinggi. Antioksidan yang tinggi dapat mencegah terjadinya reaksi oksidasi radikal bebas dalam oksidasi lipid (Trilaksani, 2004). Penelitian ini bertujuan untuk (1) Mendapatkan jenis pupuk organik yang terbaik terhadap pertumbuhan dan hasil mentimun, (2) Mengetahui populasi tanaman yang optimum terhadap pertumbuhan dan hasil mentimun dan (3) Mengetahui interaksi antara jenis pupuk organik dengan populasi tanaman terhadap pertumbuhan dan hasil mentimun.

\section{BAHAN DAN METODE}

Penelitian dilakukan di Lahan Pertanian

Fakultas Pertanian dan Peternakan UIN SUSKA Riau pada bulan Juni sampai September 2012. Bahan-bahan yang digunakan dalam penelitian ini adalah benih mentimun varietas Mercy F1(Deskripsi varietas pada Lampiran 1), pupuk kandang ayam, pupuk kompos tandan kosong kelapa sawit, pot, dan ekstrak tanaman terfermentasi. Alat-alat yang digunakan dalam penelitian ini adalah cangkul, pisau, ajir, meteran, handsprayer, timbangan, gembor, dan alat tulis.Penelitian ini merupakan percobaan dalam pot dengan $3 \times 3$ faktorial dengan menggunakan Rancangan Acak Kelompok (RAK). Faktor pertama adalah jenis pupuk organik dan faktor kedua adalah populasi tanam mentimun. Setiap perlakuan dilakukan pengulangan 4 kali sehingga diperoleh 36 unit percobaan. Faktor pertama adalah perlakuan pemberian pupuk organik yang terdiri atas: Tanpa pemberian pupuk organic (J0), Pupuk kandang ayam (J1) dan Pupuk kompos tandan kosong kelapa sawit (J2). Faktor kedua adalah populasi tanaman mentimun yang terdiri dari 1 tanaman/pot (P0), 2 tanaman/pot (P1) dan 3 tanaman/pot (P3). Data pengamatan dianlisis dengan ANOVA pada tingkat kepercayaan 95\% dan uji lanjut menggunakan DMRT.

\section{HASIL DAN PEMBAHASAN}

\section{Tinggi Tanaman}

Hasil analisis sidik ragam terhadap tinggi tanaman memperlihatkan perbedaan yang nyata untuk perlakuan jenis pupuk pada setiap waktu pengamatan. Secara keseluruhan, terlihat bahwa kontrol (tanpa pemberian pupuk) menunjukkan hasil terendah untuk tinggi tanaman dan berbeda nyata terhadap semua perlakuan lainnya. Pemberian pupuk kandang ayam (pukan ayam) menunjukkan peningkatan tinggi tanaman yang paling tinggi dan diikuti oleh pemberian pupuk kompos tandan kosong kelapa sawit (kompos TKKS) pada setiap waktu pengamatan (Grafik 1). Hal ini diduga karena pukan ayam mengandung unsur hara yang lengkap yang bermanfaat bagi pertumbuhan tanaman dan mampu memperbaiki sifat tanah.

Menurut Jumin (1991), pukan ayam mampu memperbaiki sifat fisik tanah, memperbaiki kesuburan tanah (mengandung unsur $\mathrm{N}, \mathrm{P}, \mathrm{K}, \mathrm{Mg}$ ), serta mampu meningkatkan kegiatan mikroorganisme tanah. Peranan mikroba di alam sebagai dekomposer atau pengurai bahan-bahan organik sisa tumbuhan dan hewan memang tidak dapat diabaikan. Mikroba ini akan menguraikan bahan organik menjadi lebih sederhana, sehingga dapat diserap oleh tumbuhan yang berfungsi sebagai produsen di alam (Sutedjo et al., 1991). 


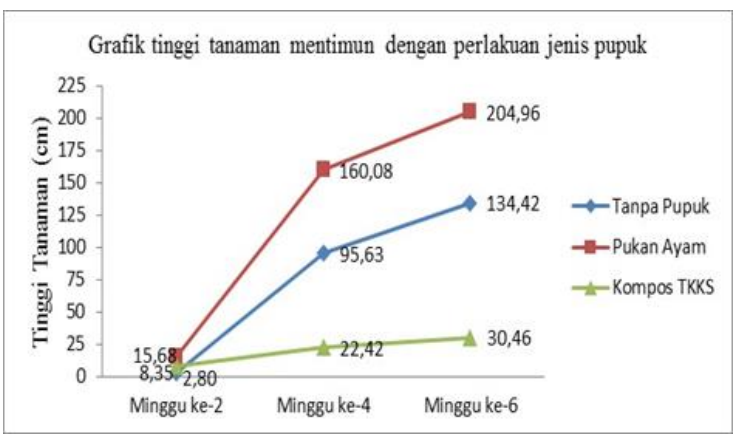

Gambar 1. Pertumbuhan tinggi tanaman mentimun dengan perlakuan jenis pupuk

\section{Diameter Batang, Jumlah daun dan Jumlah Cabang Produktif}

Interaksi pukan ayam dengan berbagai jumlah buah/tanaman menghasilkan diameter batang, jumlah daun, jumlah cabang produktif, bobot basah dan bobot kering tanaman mentimun yang lebih baik dibandingkan dengan penggunaan TKKS maupun tanpa pemberian pupuk (Tabel 1.). Tanaman yang tidak diberi pupuk, hanya memanfaatkan kandungan hara yang terdapat pada media tanam tanpa ada penambahan hara dari luar. Sementara itu pada tanaman yang diberi pukan ayam maupun TKKS mendapat tambahan unsur hara sehingga mempunyai pertumbuhan yang juah lebih baik dibandingkan tanpa pemupukan.

Berdasarkan hasil analisis tanah pada Tabel 3. terlihat bahwa kandungan hara Nitrogen sebelum dan sesudah penanaman mengalami penurunan baik pada tanaman yang dipupuk maupun yang tidak. Untuk tanaman yang diberi pupuk, jelas bahwa ada tambahan Nitrogen yang digunakan untuk membantu proses metabolisme dalam tanaman yang digunakan untuk melakukan pembelahan dan pembesaran sel sehiingga pertumbuhan vegetatif tanaman seperti pertambahan panjang batang, daun dan cabang tanaman lebih besar dibandingkan tanaman yang tidak diberi pupuk.

Menurut Lingga (1992), batang tanaman yang menghasilkan daun pada umumnya memiliki struktur reproduksi yang tegak lurus. Terjadinya pertambahan tinggi tanaman disebabkan karena adanya peristiwa pembelahan dan pemanjangan sel yang didominasi pada pucuk tanaman. Pertambahan tinggi tanaman berhubungan erat dengan penambahan jumlah daun, dimana pertambahan tinggi tanaman akan diikuti oleh pertambahan buku-buku batang yang merupakan tempat kedudukan daun tanaman.

Tabel 1. Interaksi jenis pupuk dan populasi tanaman terhadap bobot basah/tanaman, bobot kering/tanaman, diameter batang,jumlah daun dan jumlah cabang produktif mentimun

\begin{tabular}{|c|c|c|c|c|c|}
\hline Perlakuan & $\begin{array}{l}\text { Bobot Basah } \\
\text { Tanaman (g) }\end{array}$ & $\begin{array}{c}\text { Bobot } \\
\text { kering }(\mathrm{g})\end{array}$ & $\begin{array}{c}\text { Diameter } \\
\text { Batang }(\mathrm{cm})\end{array}$ & $\begin{array}{c}\text { Jumlah Daun } \\
\text { (helai) }\end{array}$ & Jumlah Cabang Produktif \\
\hline JOPO & $5,70 \mathrm{i}$ & $0,55 \mathrm{i}$ & $0,33 i$ & $5,75 i$ & $0,00 \mathrm{~g}$ \\
\hline JOP1 & $12,80 \mathrm{~g}$ & $1,36 \mathrm{~g}$ & $0,40 \mathrm{~h}$ & $7,13 \mathrm{~g}$ & $0,00 \mathrm{~g}$ \\
\hline J0P2 & $7,00 \mathrm{~h}$ & $0,92 \mathrm{~h}$ & $0,47 \mathrm{~g}$ & $6,92 \mathrm{~h}$ & $0,00 \mathrm{~g}$ \\
\hline J1P0 & $179,00 \mathrm{~b}$ & $46,50 \mathrm{a}$ & $0,85 \mathrm{a}$ & $62,50 \mathrm{a}$ & $4,75 \mathrm{a}$ \\
\hline J1P1 & $199,00 \mathrm{a}$ & $26,81 \mathrm{~b}$ & $0,79 \mathrm{~b}$ & $48,88 \mathrm{~b}$ & $4,50 \mathrm{~b}$ \\
\hline J1P2 & $141,50 \mathrm{c}$ & $16,98 \mathrm{c}$ & $0,74 \mathrm{c}$ & $35,58 \mathrm{c}$ & $3,25 \mathrm{c}$ \\
\hline J2P0 & $103,60 \mathrm{~d}$ & $14,38 d$ & $0,73 d$ & $30,00 d$ & $2,25 d$ \\
\hline J2P1 & $92,80 \mathrm{e}$ & $12,41 \mathrm{e}$ & $0,65 \mathrm{e}$ & $28,25 \mathrm{e}$ & $1,88 \mathrm{e}$ \\
\hline J2P2 & $67,70 \mathrm{f}$ & $8,58 \mathrm{f}$ & $0,61 \mathrm{f}$ & $20,33 \mathrm{f}$ & $1,58 \mathrm{f}$ \\
\hline
\end{tabular}

Keterangan : Angka-angka yang diikuti oleh huruf kecil yang sama tidak berbeda nyata menurut uji DMRT pada taraf $5 \%$.

\section{Jumlah buah/tanaman dan bobot buah/tanaman}

Pembentukan buah dipengaruhi oleh banyaknya fotosintat yang dihasilkan selama pertumbuhan dan perkembangan tanaman. Salah satu satu faktor yang mempengaruhi besarnya fotosintat yang dihasilkan adalah ketersediaan unsur hara yang ada di dalam tanah. Salah satu unsur hara yang menentukan pembentukan buah adalah fosfor dan kalium. Pada pengamatan jumlah buah/tanaman dan bobot buah/tanaman (Tabel 2.) terlihat bahwa tanaman yang diberi pukan ayam maupun
TKKS secara nyata lebih baik dibandingkan dengan tanaman yang tidak diberi pupuk. Tanaman yang tidak diberi pupuk hanya memanfaatkan unsur hara yang berada di dalam tanah saja sehingga fotosintat yang terbentuk jauh lebih sedikit dibandingkan tanaman yang diberi pupuk bahkan pada tanaman yang kombinasi perlakuan tanpa pemupukan dan populasi 1 tanaman/pot (JOPO) tidak menghasilkan buah sama sekali.

Tanaman yang diberi pukan ayam secara nyata menghasilkan buah yang jumlahnya lebih banyak dibandingkan tanpa 
pupuk maupun pemberian pupuk kompos TKKS. Hal ini disebabkan karena pupuk kandang ayam mengandung banyak bahan organic diantaranya adalah nitrogen, fosfor dan kalsium. Menurut hasil penelitian Dauda et al. (2008) jumlah buah semangka yang dihasilkan pada pemberian pupuk kandang ayam secara nyata lebih tinggi dbandingkan pada tanaman yang tidak diberi pupuk kandang. Adanya peningkatan jumlah buah ini buah mungkin dapat disebabkan karena kemampuan pupuk kandang ayam untuk meningkatkan vigor, aktivitas meristem dan fisiologi pada tanaman karena adanya ketersediaan nutrisi tanaman dan peningkatan kondisi tanah sehingga menyebabkan peningkatan fotosintat yang digunakan untuk pembentukan buah.

Hasil penelitian yang lain juga menyatakan bahwa peningkatan jumlah buah disebabakan karena adanya peningkatan aplikasi pupuk nitrogen. Berdasarkan hasil analisis tanah, pada Tabel 3. terlihat bahwa ketersediaan unsur hara $\mathrm{N}$ semakin menurun dengan bertambahanya umur tanaman. Hal ini menunjukkan bahwa tanaman cukup banyak menyerap unsure hara $\mathrm{N}$ selama pertumbuhannya.

Tabel 2. Interaksi jenis pupuk dan populasi tanaman terhadap jumlah buah/tanaman, bobot buah/tanaman, jumlah buah/pot, bobot buah/pot dan bobot/buah

\begin{tabular}{cccccc}
\hline Perlakuan & $\begin{array}{c}\text { Jumlah } \\
\text { buah/tanaman }\end{array}$ & $\begin{array}{c}\text { Bobot } \\
\text { buah/tanaman }\end{array}$ & $\begin{array}{c}\text { Jumlah } \\
\text { buah/pot }\end{array}$ & $\begin{array}{c}\text { Bobot buah/ } \\
\text { pot }(\mathrm{g})\end{array}$ & Bobot/ buah $(\mathrm{g})$ \\
\hline J0P0 & $0,00 \mathrm{i}$ & $0,00 \mathrm{i}$ & $0,00 \mathrm{~g}$ & $0 \mathrm{i}$ & $0,00 \mathrm{i}$ \\
J0P1 & $0,38 \mathrm{~g}$ & $3,00 \mathrm{~h}$ & $0,75 \mathrm{f}$ & $6 \mathrm{~h}$ & $3,10 \mathrm{~h}$ \\
J0P2 & $0,25 \mathrm{~h}$ & $5,00 \mathrm{~g}$ & $0,75 \mathrm{f}$ & $14 \mathrm{~g}$ & $4,60 \mathrm{~g}$ \\
J1P0 & $5,75 \mathrm{a}$ & $1700,00 \mathrm{a}$ & $5,75 \mathrm{c}$ & $1700 \mathrm{c}$ & $295,70 \mathrm{a}$ \\
J1P1 & $4,38 \mathrm{~b}$ & $941,00 \mathrm{~b}$ & $8,75 \mathrm{~b}$ & $1883 \mathrm{~b}$ & $213,20 \mathrm{~b}$ \\
J1P2 & $3,92 \mathrm{c}$ & $817,00 \mathrm{c}$ & $11,75 \mathrm{a}$ & $2450 \mathrm{a}$ & $200,40 \mathrm{~d}$ \\
J2P0 & $2,25 \mathrm{e}$ & $466,00 \mathrm{~d}$ & $2,25 \mathrm{e}$ & $466 \mathrm{f}$ & $206,50 \mathrm{C}$ \\
J2P1 & $2,38 \mathrm{~d}$ & $388,00 \mathrm{e}$ & $4,75 \mathrm{~d}$ & $775 \mathrm{~d}$ & $150,00 \mathrm{e}$ \\
J2P2 & 1,58 f & $206,00 \mathrm{f}$ & $4,75 \mathrm{~d}$ & $618 \mathrm{e}$ & $127,90 \mathrm{f}$ \\
\hline
\end{tabular}

Keterangan : Angka-angka pada kolom yang sama yang sama yang diikuti oleh huruf kecil yang sama tidak berbeda nyata menurut uji DnMRT pada taraf $5 \%$.

Buah yang dihasilkan pada pemberian pukan ayam dan populasi 1 tanaman per pot yang berbeda nyata dengan kombinasi perlakuan lainnya, diikuti oleh jumlah populasi 2 dan 3 tanaman per pot. Penurunan jumlah buah per tanaman seiring dengan bertambahnya populasi juga terjadi pada pemberian pupuk kompos TKKS. Penggunaan pupuk kompos TKKS menghasilkan jumlah buah per tanaman yang tidak berbeda nyata pada populasi 1 maupun 2 tanaman per pot akan tetapi pada populasi 3 tanaman per pot terjadi penurunan jumlah buah secara nyata. Penurunan ini terjadi karena tanaman yang tumbuh pada populasi yang lebih tinggi mengalami persaingan yang lebih ketat dalam mendapatkan unsur hara, sinar matahari maupun air sehingga pertumbuhan dan perkembangan tanaman tidak maksimal. Meskipun demikian jumlah buah total yang dihasilkan pada pemberiaan pupuk kompos TKKS yang terbanyak adalah pada populasi 2 tanaman per pot dan berbeda nyata dengan perlakuan lainnya.

Interaksi antara perbedaan jenis pupuk dan populasi tanaman berpengaruh nyata terhadap bobot buah yang dihasilkan. Setiap kombinasi perlakuan yang dicobakan memberikan pengaruh yang saling berbeda nyata. Tanaman yang tidak diberi pupuk menghasilkan bobot buah terendah, diikuti pemakaian pupuk kompos TKKS dan bobot buah tertinggi pada pemakaian pupuk kandang ayam. Pupuk kandang yang diberikan ke tanaman menyebabkan tanah menjadi lebih subur karena mempunyai kandungan $\mathrm{N}, \mathrm{P}$ dan $\mathrm{K}$ yang lebih tinggi sehingga unsur tersebut dapat digunakan oleh tanaman untuk perkembangan buahnya.

Tabel 3. menunjukkan bahwa kandungan unsure $P$ yang terdapat pada pupuk kandang ayam paling tinggi dibandingkan kompos TKKS. Begitu juga dengan kandungan kaliumnya. Besarnya unsur hara inilah yang menyebabkan tanaman menghasilkan buah yang mempunyai ukuran lebih besar. Pukan ayam mempunyai sifat yang lebih baik dibandingkan pupuk alam lainnya maupun dengan pupuk buatan. Sebagai persediaan zat makanan di dalam tanah, pupuk kandang mempunyai pengaruh susulan untuk waktu lama, artinya secara bertahap akan bebas tetapi secara bertahap pula akan tersefia kembali bagi tanaman (Sutedjo, 2008). Hasil penelitian Onyia et al. (2012) bobot buah yang 
dihasilkan oleh mentimun dipengaruhi oleh jenis pupuk yang digunakan. Pemberian pupuk kandang ayam secara nyata meningkatkan berat buah per plot dibandingkan pada tanaman control akan tetapi menghasilkan buah yang lebih ringan dibandingkan pemberian pupuk NPK dan urea.

Berdasarkan hasil penelitian Hamma et al. (2012) pemberian pupuk kandang ayam terhadap pertumbuhan dan hasil mentimun memberikan pengaruh yang positif. Semakin besar dosis pupuk yang digunakan bobot buah per tanaman yang dihasilkan juga semakin meningkat secara nyata. Ogbonna dan Obi (2007) menyatakan bahwa melon yang diberi pupuk kandang menghasilkan bobot buah per hektar yang tinggi. Hal ini terjadi karena pupuk kandang mampu meningkatkan kandungan kimia tanah sehingga memacu pertumbuhan dan hasil tanaman. Tanaman melon yang diberi pupuk kandang menghasilkan biji per tanaman yang secara nyata meningkat dibandingkan yang tanpa diberi pupuk kandang ayam. Terjadi peningkatan $58,7 \%$ dan $62 \%$ pada pemberian pupuk kandang ayam 5 dan 10 ton/ha dibanding tanpa pemupukan. Pupuk kandang dianggap sebagai pupuk lengkap karena selain menimbulkan tersedianya unsure-unsur bagi tanaman, juga mengembangkan kehidupan mikroorganisme (jasad renik) di dalam tanah. Jasad renik sangat penting bagi kesuburan tanah, seresah dan sisa-sisa tanaman dapat diubahnya menjadi humus, senyawa-senyawa tertentu disintesanya menjadi bahan-bahan yang berguna bagi tanaman (Sutedjo, 2008).

Penurunan bobot buah per tanaman terjadi secara linier seiring dengan penambahan populasi tanaman per pot. Bobot buah per tanaman tertinggi diperoleh pada perlakuan pemberian pupuk kandang ayam dan populasi 1 tanaman per pot, diikuti oleh 2 dan 3 tanaman per pot begitu juga pada penggunaan pupuk tandan kososng kelapa sawit. Hasil penelitian ini sejalan dengan Briuen (1979) cit. Ayodele dan Salami (2006), dengan jarak tanam yang lebih lebar akan meningkatkan ukuran buah dan jumlah buah per tanaman melon karena populasi tanaman menurun akan tetapi hal ini akan menurunkan hasil buah. Bobot buah terendah diperoleh pada kombinasi perlakuan tanpa pemupukan dan populasi 1 tanaman per pot. Pada perlakuan ini tanaman tidak menghasilkan buah sama sekali.

\section{Jumlah buah dan bobot buah per pot serta bobot buah mentimun per biji}

Jumlah dan bobot buah per pot yang dihasilkan pada setiap pot percobaan semakin banyak dengan semakin banyanya populasi yang ada pada setiap pot. Akan tetapi hal ini berkebalikan dengan bobot per buah yang dihasilkan oleh tanaman. Berat per buah mentimun semakin kecil dengan semakin banyaknya populasi pada masing-masing pot pada pemupukan pupuk kandang ayam dan tandan kosong kelapa sawit. Namun, pada tanaman yang tidak diberi pupuk, justru terjadi hal yang sebaliknya.

Jumlah buah terbanyak dihasilkan pada kombinasi perlakuan pukan ayam dan jumlah tanaman 3 tanaman per pot diikuti oleh 2 dan 1 tanaman per pot. Buah yang muncul dari perlakuan ini diduga disebabkan karena tanaman mendapatkan unsure hara yang berasal dari media tumbuhnya. Pukan ayam yang diberikan ke dalam tanah memberikan pengaruh yang sangat baik karena dapat memperbaiki sifat fisik tanah yaitu karena mampu menambah zat makanan, mempertinggi kadar humus, memperbaiki struktur tanah, dan mendorong kehidupan jasad renik (Sutedjo, 2008).

Selain itu menurut Rahman (2004) cit. Dauda et al. (2007) menyatakan bahwa pukan ayam relatif tahan terhadap degradasi mikroba tanah. Namun demikian adalah sangat penting dan esensial untuk menciptakan dan memelihara kondisi fisik tanah yang optimum dan pertumbuhan tanaman. Selain itu pukan ayam harganya sangat murah dan efektif sebagai sumber nitrogen untuk produksi tanaman berkelanjutan tetapi keberadaannya tetap menjadi isu yang penting karena tidak dapat ditemukan di setiap tempat sedangkan. Berdasarkan hasil analisis tanah (Tabel 4.3) terlihat bahwa penggunaan pukan ayam maupun kompos TKKS kandungan unsure hara fosfor dan kalium pada saat panen masih sangat banyak. Fosfor yang tertinggal di dalam tanah sekitar 2 kali kandungan fosfor sebelum penanaman sedangkan kaliumnya sekitar 5 kali.

Hal ini menunjukkan bahwa fosfor dan kalium yang tersedia dalam tanah sangat banyak dan dapat terserap oleh tanaman dengan baik dengan kata lain semua kebutuhan tanaman sudah cukup terpenuhi sehingga sampai meninggalkan residu unsure hara yang cukup banyak. Kelebihan-kelebihan inilah yang menyebabkan tanaman mentimun yang diberi 
pupuk kandang mempunyai jumlah buah per pot yang nyata lebih tinggi dibanding pemberian pupuk lainnya.

Total jumlah buah yang dihasilkan pada jumlah tanaman 2 dan 3 tanaman per pot tidak memberikan pengaruh nyata tetapi lebih banyak dibandingkan dengan jumlah populasi 1 tanaman per pot. Sedikitnya jumlah buah yang dihasilkan pada penanaman dengan populasi yang lebih sedikit terjadi karena setiap tanaman mempunyai batasan tertentu untuk dapat menghasilkan buah sehingga dengan semakin banyak populasi yang ada maka akumulasi jumlah buah yang disumbangkan juga akan semakin banyak. Dengan adanya peningkatan jumlah tanaman per lubang tanam maupun peningkatan populasi tanaman, memungkinkan terbentuknya daun yang lebih banyak sehingga tanaman mempunyai luas daun dan indeks luas daun yang lebih besar sehingga cahaya matahari dapat digunakan secara maksimal oleh tanaman untuk melakukan proses fotosintesis dengan lebih baik. Dengan demikian akan dihasilkan fotosintat yang lebih banyak. Fotosintat yang dihasilkan ini akan didistribusikan ke seluruh organ tanaman yang membutuhkan misalnya untuk pembentukan buah. Peningkatan populasi ini tidak selamanya memberikan pengaruh positif terhadap jumlah buah yang dihasilkan karena semakin banyak populasi maka persaingan antar tanaman dalam mendapatkan sinar matahari, air, unsure hara dan factor pertumbuhan lainnya juga akan semakin meningkat.

Hasil penelitian ini sejalan dengan hasil penelitian Ayodele dan Salami (2006), terjadi penurunan jumlah buah melon yang dihasilkan seiring dengan penurunan populasi tanaman per hektar begitu juga dengan perlakuan perbedaan populasi per lubang tanam, didapatkan hasil bahwa semakin banyak jumlah tanaman per lubang tanam, maka jumlah buah yang dihasilkan juga akan semakin banyak. Hasil serupa juga diperoleh dari hasil penelitian Maynard dan Scott (1998), jumlah buah melon yang dihasilkan per hektar meningkat dengan terjadinya peningkatan populasi tanaman dari 3074 sampai 10764 tanaman per hektar. Begitu juga dengan hasil penelitian Kultur et al. (2001), terjadi peningkatan jumlah buah melon $23,5 \%$ dengan pengurangan populasi tanaman $50 \%$ (dari 72600 menjadi 36300 tanaman/hektar. Berdasarkan hasil penelitian Babayee et al. (2012) bahwa jumlah biji labu yang dihasilkan akan semakin banyak dengan meningkatnya kepadatan populasi tanaman per hektarnya. Populasi tanaman 6000, 8000 dan 10000 per hektar tidak menghasilkan jumlah biji yang berbeda nyata akan tetapi pada populasi 12000 tanaman per hektar justru menghasilkan biji yang lebih sedikit dibandingkan pada populasi tanaman 6000 dan 10000 tanaman per hektar.

Table 3. Hasil analisis kandungan unsure hara pada media tanam

\begin{tabular}{lcccccccc}
\hline \multirow{2}{*}{ Perlakuan } & \multicolumn{4}{c}{ Awal penanaman } & \multicolumn{5}{c}{ Saat panen } \\
\cline { 2 - 9 } & $\begin{array}{c}\mathrm{N} \text { total } \\
(\%)\end{array}$ & $\begin{array}{r}\mathrm{P}_{2} \mathrm{O}_{5} \\
(\mathrm{ppm})\end{array}$ & $\mathrm{K}(\%)$ & $\begin{array}{c}\mathrm{pH} \\
\mathrm{H}_{2} \mathrm{O}\end{array}$ & $\begin{array}{c}\mathrm{N} \text { total } \\
(\%)\end{array}$ & $\begin{array}{r}\mathrm{P}_{2} \mathrm{O}_{5} \\
(\mathrm{ppm})\end{array}$ & $\mathrm{K}(\%)$ & $\begin{array}{c}\mathrm{pH} \\
\mathrm{H}_{2} \mathrm{O}\end{array}$ \\
\hline J0P0 & 0,14 & 29,49 & 0,16 & 3,42 & 0,52 & 26,85 & 1,14 & 4,58 \\
J0P1 & 0,81 & 30,78 & 0,84 & 3,43 & 0,59 & 25,87 & 0,83 & 4,24 \\
J0P2 & 0,58 & 29,79 & 0,85 & 4,42 & 0,46 & 27,05 & 0,88 & 4,09 \\
J1P0 & 0,69 & 90,55 & 0,88 & 4,03 & 0,52 & 184,82 & 6,01 & 5,36 \\
J1P1 & 0,74 & 90,16 & 0,77 & 4,09 & 0,59 & 175,17 & 5,02 & 4,96 \\
J1P2 & 0,76 & 113,41 & 1,25 & 3,28 & 0,63 & 213,26 & 6,63 & 5,45 \\
J2P0 & 0,53 & 44,10 & 0,46 & 3,85 & 0,84 & 60,35 & 2,82 & 4,46 \\
J2P1 & 0,78 & 38,20 & 0,62 & 3,82 & 0,86 & 68,40 & 2,38 & 4,37 \\
J2P2 & 0,80 & 44,77 & 0,63 & 3,93 & 0,75 & 51,94 & 2,02 & 4,21 \\
\hline
\end{tabular}

Pemberian pupuk kandang ayam dan pupuk kompos tandan kelapa sawit memberikan pengaruh yang berbeda terhadap pertumbuhan dan hasil tanaman mentimun. Media tanam yang digunakan mengalami penaikan $\mathrm{pH}$ tana. $\mathrm{pH}$ tanah pada saat akhir penelitian meningkat jika dibandingkan pada awal penanaman.

Kandungan unsur hara yang terdapat pada pupuk kandang ayam dan pupuk kompos TKKS secara nyata mampu meningkatkan kandungan N, P dan K pada tanah. Kenaikan kandungan unsur hara ini disebabkan karena 
pupuk telah mengalami dekomposisi dan telah bercampur dengan tanah sehingga dapat dimanfaatkan oleh tanaman untuk pertumbuhan vegetatif maupun generatif tanaman. Kandungan $\mathrm{N}$ pada pukan ayam lebih banyak diserap oleh tanaman dibandingkan pada pupuk kompos TKKS. Pada pemberian pukan ayam, terjadi penyerapan unsur $\mathrm{N}$ yang lebih tinggi sehingga tanaman menyerap unsur tersebut selain dari pupuk yang diberikan juga dari media tanamnya. Lain halnya pada pupuk kompos TKKS, kebutuhan $\mathrm{N}$ diperolehnya pada pupuk yang diberikan saja sehingga tidak mengurangi kandungan unsur hara pada media tanamnya.

Tingginya kandungan $\mathrm{P}$ dan $\mathrm{K}$ pada pukan ayam dan kompos tandan kosong kelapa sawit menyebabkan residu yang tertinggal di dalam tanah cukup banyak sehingga tanah bekas penanaman mentimun ini memiliki kandungan $P$ dan $K$ yang lebih tinggi dibandingkan tanah pada saat penelitian. Residu unsur hara $\mathrm{K}$ yang tersisa di dalam media tanam semakin sedikit dengan semakin tingginya populasi tanaman per pot, begitu juga unsur $\mathrm{P}$ nya pada pukan ayam.

\section{KESIMPULAN DAN SARAN}

\section{Kesimpulan}

Pupuk kandang ayam dan kompos
tandan kelapa sawit meningkatkan pertumbuhan dan hasil mentimun. Peningkatan pertumbuhan dan hasil mentimun lebih baik pada pemberian pupuk kandang ayam dibandingkan kompos tandan kelapa sawit. Semakin banyak populasi tanaman per pot, semakin banyak dan berat buah yang dihasilkan per pot tetapi menurunkan jumlah daun, diameter batang, bobot kering tanaman, jumlah cabang produktif, ukuran buah dan berat buah per tanaman.

\section{Saran}

Untuk meningkatkan hasil mentimun disarankan menggunakan pupuk kanadang ayam maupun kompos tandan kosong kelapa sawit.

\section{Ucapan Terima Kasih}

Terima kasih yang sebesar-besarnya kepada DIPA Fakultas Pertanian dan Peternakan UIN Suska Riau sebagai penyandang dana pada penelitian ini, Werman dan teman-teman yang telah membantu pelaksanaan penelitian.

\section{DAFTAR PUSTAKA}

Ayodele, O.J dan A.E. Salami. 2006. Physiological response of two variants of egusi melon (Citrullus lanatus) to plant population density in a humid environment. Journal of Food, Agriculture \& Environment. 4 (3\&4) : 110-113.

Babayee, S.A., J. Daneshian dan S.A.R. Valadabadi. 2012. Effect of plant density and irrigation interval on some grain characteristics of pumpkin (Cucurbita pepo L.). International Journal of Agriculture and Crop Sciences. IJACS Journal. 4(8): 439-442.

Dauda, S.N., F.A. Ajayi dan E. Ndor. 2008. Growth and Yield of Watermelon (Citrullus lanatus) as affected by poultry manure application. Journal of Agriculture \& Social Sciences. 4(3): 121124.

Hakim, N., M.Y. Nyakpa, A.M. Lubis, S.G. Nugroho, M.R. Saul, M.A. Diha, G.B. Hong dan H.H. Bailey. 1986. Dasardasar IImu Tanah. Universitas Lampung. Lampung.

Hamma, I.L., U. Ibrahim dan M. Haruna. 2012. Effect of poultry manure on the growth and yield of cucumber (Cucumis sativum I.) in Samaru, Zaria. Nigerian Journal of Agriculture, Food and Environment. 8(1):94-98.

Maynard, E.T dan W.D. Scott. 1998. Plant spacing affects yield of 'Superstar' muskmelon. HortScience. 33(1): 52-54.

Ogbonna, P.E dan I.U. Obi. 2007. Effect of time of planting and poultry manure application on growth and yield of egusi melon (Colocynthis citrullus I.) in a derived Savannah agro-ecology. Journal of Agriculture, Food, Environment and Extension. 6 (2): $33-39$. 
Onyia, V.N., T. S. Emavwodia., C. O. Mbuka, and G. C. Onyishi. 2012. Interrelationship between yield and yield components in cucumber (Cucumis sativus) in Enugu, South-eastern, Nigeria. African Journal of Agricultural Research. 7(25): 3781-3785.

Sarief, E.S. 1985. Kesuburan dan Pemupukan Tanah Pertanian. Pustaka Buana. Bandung.

Sutedjo, M.M., Kartasapoetra dan A.G. Sastroamodjo. 1991. Mikrobiologi Tanah.

PT. Rineka Cipta. Jakarta. 


\section{$\mathbf{J}$

PERUBAHAN SIFAT KIMIA TANDAN KOSONG KELAPA SAWIT YANG DIFERMENTASI DENGAN EM4 PADA DOSIS DAN LAMA PEMERAMAN YANG BERBEDA

Changes Of Chemical Properties Compost Oil Palm Empty Fruit Bunch Fermented With Em4 Dosage And Long Different Ripening

Abdul Rahman Toiby, Elfi Rahmadani, dan Oksana

PEMANFAATAN BEBERAPA JENIS DAN DOSIS LIMBAH KELAPA SAWIT (Elaeis guinensis Jacq) TERHADAP PERUBAHAN PH, N, P, K TANAH PODSOLIK MERAH KUNING (PMK)

Fitri Ramadhani, Ervina Aryanti, dan Robbana Saragih

UPAYA PENINGKATAN HASIL MENTIMUN SECARA ORGANIK DENGAN SISTEM TASALAMPOT

Increasing the Yields of Cucumber by Tasalampot Organic Farming System

Indah Permanasari dan Aulia Rani Annisava

PERTUMBUHAN BIBIT KELAPA SAWIT (Elaeis guineensis Jacq.) DI PEMBIBITAN UTAMA PADA MEDIUM SUB SOIL ULTISOL YANG DIBERI ASAM HUMAT DAN KOMPOS TANDAN KOSONG KELAPA SAWIT

The Growth of Palm Seedlings (Elaeis guineensis Jacq.) at the Experiment Farm By Using Medium Of Subsoil Ultisol That Was Treated With Humic Acid and Fruitless Palm Bunch Compost

Janrico Valentino Sembiring, Nelvia, dan Arnis En Yulia

INDUKSI KALUS PASAK BUMI (Eurycoma longifolia Jack) MELALUI EKSPLAN DAUN DAN PETIOL

Callus Induction of Eurycoma longifolia Jack by Leaf and Petiole Explant

Rosmaina, Zulfahmi, Probo Sutejo, Ulfiatun, dan Maisupratina

KEPADATAN DAN POLA PENYEBARAN PASAK BUMI (Eurycoma longifolia Jack) DI ZONA ALAMAN KUYANG, HUTAN LARANGAN ADAT KENEGARIAN RUMBIO

Density and Distribution Pattern of Eurycoma longifolia Jack) In The Alaman Kuyang Zone of The Forest Reserve of Kenegarian Rumbio

Zulfahmi, Nelawati, Rosmaina 